\title{
Tuberculosis in the New World: a study of ribs from the Schild Mississippian population, West-Central Illinois
}

\author{
Jennifer Raff, Della Collins Cook ${ }^{+}$, Frederika Kaestle
}

\author{
Departments of Anthropology and Biology, Indiana University, Student Building, 701 East Kirkwood, Bloomington, \\ Indiana 47405-7100, US
}

\begin{abstract}
Vertebral lesions have been the main evidence for infection by the Mycobacterium tuberculosis complex (MTC) in paleopathology. Skeletal involvement is expected in a small percentage of infected individuals. Recently, several authors report a correlation between rib lesions and tuberculosis (TB) complex infection. This study tests the hypothesis that rib lesions can serve as a useful marker for MTC infection within the Mississippian Schild skeletal collection from West-Central Illinois. Ribs from 221 adults and juveniles were examined, and affected individuals were tested for TB complex infection. DNA from rib samples of affected individuals was amplified with primers targeting the IS6110 insertion element, which is common to all members of the TB complex. Although it cannot allow discrimination between different species of TB, IS6110 is present in many copies within their genomes, and its presence is thus an indication of MTC infection. The results support the use of rib lesions as a marker for TB infection. Additionally, we demonstrate that MTC DNA can be recovered from ribs that lack lesions in individuals who have lesions of other bones. We recommend that an examination of ribs be incorporated into investigations for TB.
\end{abstract}

Key words: rib periosteal lesions - tuberculosis - Mississippian - North America

The discovery that tuberculosis (TB) is a pre-contact Native American disease has encouraged research into its origins and distribution within prehistoric American populations. A review of the data for North America suggests that the first cases of tuberculosis infection appear around $1000 \mathrm{AD}$, and the infections are most frequently reported for sites in the Midwest and Southwest (although it should be noted that this pattern may be the result of preservation and sampling biases (Merbs 1992, Roberts \& Buikstra 2003). In the Midwest, the date of apparent TB emergence loosely corresponds to the Late Woodland/Mississippian cultural transition, which is characterized by (among other things) an increased population size and density, a decrease in dietary quality, increased movement of goods (and perhaps people) along extensive trade routes, and other stress such as warfare (Roberts \& Buikstra 2003).

TB disease is caused by members of the TB complex, which includes Mycobacterium tuberculosis (maintained in human populations), Mycobacterium bovis (maintained in non-human mammalian populations), and several other species (for a review of this disease and potential virulence factors, see Smith 2003). Skeletal involvement generally occurs in a small percentage of the infected population (less than 1\% according to Daniel et al. 1981), and of those individuals whose skeletons are affected, some 1-

Financial support: Indiana University to FK, and NSF IGERT program to JAR

${ }^{+}$Corresponding author: cook@indiana.edu

Received 20 July 2006

Accepted 16 October 2006
$8 \%$ will manifest periostitis of the visceral surfaces of the ribs (Mays et al. 2002). The correlation between rib lesions and TB infection has been the subject of several recent studies (Santos \& Roberts 2001, Mays et al. 2002, Lambert 2002, and reviewed in Roberts \& Buikstra 2003) as well as some earlier studies (Kelly \& Micozzi 1984, Eyler et al. 1996). Although several other diseases, including pneumonia, actinomycosis, cancer, and blastomycosis can produce rib lesions, and thus rib lesions are insufficient in themselves to diagnose TB (Pfeiffer 1991, Buikstra \& Williams 1991, Roberts et al. 1994, Lambert 2002), the correlation between TB infection and rib periostitis is strong enough to make a preliminary assessment (Lambert 2002). Such an assessment can form a starting point for a molecular-based survey of the infected population, as is the purpose of this current study.

Bone infection (or trauma) causes an inflammatory response that stimulates the production of new bone along the periosteal surface. The appearance of this bone runs a continuum from woven bone in the early stages of healing to dense, smooth surfaced new bone that is confluent with the original surface. In the case of tuberculosis, rib lesions are most often found on the pleural (internal surface) of the ribs (Santos \& Roberts 2001, Mays et al. 2002, Lambert 2002, Roberts \& Buikstra 2003, Matos \& Santos 2006).

The presence of TB in the prehistoric Midwest has been established by numerous studies, including several on the Schild Cemetery from Greene County Illinois (AD1000 to 1200). The Schild Cemetery is in the hinterlands of Cahokia, the largest Pre-Columbian community in North America. Because of its considerable population size (estimates range between 4000 and as much as 25,000 , with regional estimates as high as 50,000 according to Milner 1998), Mississippian-period Cahokia, and by inference neighboring rural areas such as Schild, are thought 
to be a more likely environment for the spread and maintenance of TB than the earlier (and more sparsely populated) Late and Middle Woodland occupations of the region (Buikstra \& Cook 1981). As skeletal material from Cahokia is badly preserved, the Schild collection provides an important resource in studying the Mississippian period. Buikstra (1977), Cook (1980), and Buikstra and Cook (1981) have reported the presence of vertebral lesions suggestive of TB among the Mississippian burials (but not the Late Woodland burials) at Schild. These lesions most frequently take the form of "cystic resorption within only one or two vertebral bodies with little to no proliferative response or involvement of other elements" (Buikstra \& Cook 1981). In some cases, such as SB201, a 20-22 year old female (dated to $1050 \mathrm{AD}$ ), the lesions were quite severe; SB201 had such extensive vertebral destruction that it probably necessitated burial in a flexed position, rather than the more common extended burial position (Braun et al. 1998). Braun et al. (1998) confirmed the presence of TB in this individual through the amplification of the IS6110 insertion sequence common to members of the TB complex.

Although vertebrae are the most common skeletal element examined for evidence of tubercular lesions, it has been documented that ribs are also frequently infected, and may be an under-utilized source of data for paleopathological studies. Ribs from the Schild collection have not previously been specifically examined for evidence of lesions, and may provide an additional means of screening individuals for further molecular diagnosis.

\section{MATERIALS AND METHODS}

All ribs preserved in the Schild population (221 individuals) were examined for pathology. The presence/absence of periosteal lesions or other pathologies were documented for each individual, and the anatomical location was noted as well as the affected surface (internal or external). Following Lambert (2002), lesions were classified according to their stage of healing: woven bone, remodeling or lamellar bone.

As part of an ongoing investigation of the incidence of infection at Schild, individuals exhibiting rib lesions consistent with infection (but not trauma) were tested for TB infection. A sample of $0.5 \mathrm{~g}$ of bone taken from a nonpathological rib was UV-irradiated at $254 \mathrm{~nm}$ at a distance of 5 inches for 5 min each side to crosslink contaminating DNA, soaked in undiluted bleach for 5-10 min, then rinsed in DNA-free $\mathrm{H}_{2} \mathrm{O}$ for 5-10 min. The sample was powdered, decalcified in $0.5 \mathrm{mM}$ EDTA for $1-3$ days at $40^{\circ} \mathrm{C}$, then di- gested overnight at $50^{\circ} \mathrm{C}$ with $200 \mu \mathrm{l}$ of $20 \mathrm{mg} / \mathrm{ml}$ proteinase K. DNA was extracted using QBioGene Systems Ancient DNA Extraction kit, which is a silica-based purification method, and in some cases further purified and concentrated using a Microcon-100 concentrator. Polymerase chain reaction (PCR) was used to amplify the insertion sequence $I S 6110$ in a nested PCR reaction designed specifically for ancient samples, as reported in Braun et al. (1998). Amplification products were sequenced to confirm specificity following the BigDye Terminator v3.1 Cycle Sequencing Kit manufacturer's protocol (Applied Biosystems) and sequences were visualized on an Applied Biosystems 3730 automated sequencing system. Sequences were analyzed using Sequencher 4.5 software (Gene Codes Corp. 2005).

Strict precautions for preventing and detecting contamination were followed. All pre-PCR manipulations took place in an isolated, positive pressure laboratory with HEPA-filtered air. Investigators working in the ancient DNA laboratory wore disposable, protective clothing such as lab coats, face masks, hairnets, gloves, and dedicated shoes. All reagents used in the ancient DNA laboratory are certified molecular grade and/or filtered through a 0.22 $\mu \mathrm{M}$ filter to remove DNA, and all equipment was UV irradiated or bleached regularly. Negative controls were employed at each step in the extraction and amplification process to detect contamination. The laboratory is bleached weekly, and is UV irradiated for $2 \mathrm{~h}$ after each use. Post-PCR manipulations took place in a separate laboratory; to minimize the risk of transferring amplified DNA into the isolation laboratory, investigators do not enter the ancient laboratory within the same day after working in the modern laboratory.

\section{RESULTS}

Five individuals, SA41, SB297, SB269, SB250, and SB201, constituting $2.3 \%$ of the adult population studied, had multiple lesions of notable size on their ribs (Table and Figure). IS6110 was amplified from all of these samples, but not from an individual with lesions consistent with trauma (SA52), or from any negative controls. An additional two individuals (SA96a and SB259a) without rib lesions also tested positive for TB. SB259a has fine periosteal new bone formation on all long bones, particularly the tibias, low bone mass, and small focal destructive lesions in the hands that were not considered diagnostic of TB in previous studies (Cook 1980). The sequence of the IS6110 amplifications was identical to TB complex members published on GenBank.

TABLE

Description of periosteal rib lesions at Schild (after Lambert 2002)

\begin{tabular}{llllll}
\hline Burial & Age & Sex & Affected ribs & Primary locations & Stage of pathogenesis \\
\hline SA41 & Adult & M & R/6-8,10 L/4 middle fragments & Vertebral half, body & Remodeling \\
SB297 & $27-30$ & M & R/2-3 & Sternal half & Woven \\
SB201 & $20-25$ & F & L/1-3, 6-8, R/3L\&R/12 & Sternal half, vert. half, entire rib & Remodeling \\
SB269 & $47+$ & F & R/5-8,11L/2-4 & Sternal half, vertebral half & Woven \\
SB250 & $42-47$ & M & R/2 & Body & Woven \\
\hline
\end{tabular}




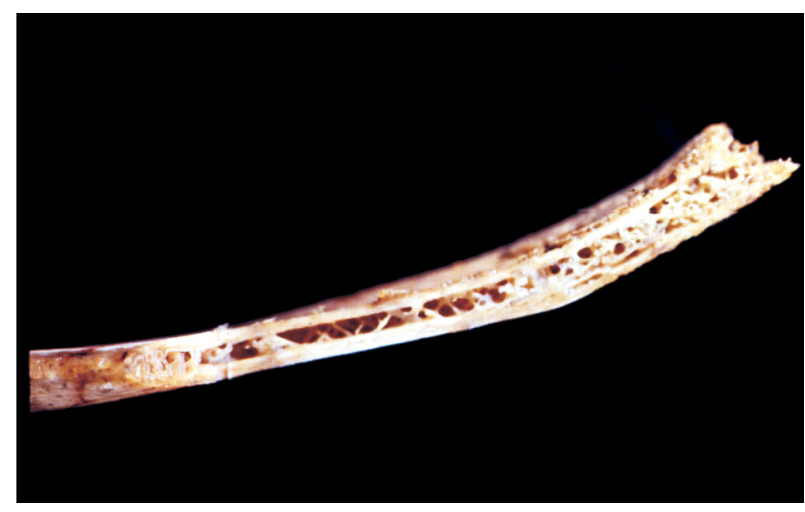

Sectioned right second rib of SB297, showing periosteal lesion on the visceral surface.

\section{DISCUSSION}

All individuals identified in this study with periosteal rib lesions suggestive of systemic infection, rather than trauma, were confirmed as TB positive through ancient DNA analysis. These results indicate that TB infection was widespread within a prehistoric Mississippian population, although it is important to note that IS6110 cannot discriminate between different species of the TB complex. Further molecular testing should identify TB infections in individuals without bone lesions, in order to provide a more accurate estimate of the incidence of the disease within this population.

This study supports the hypothesis that periosteal rib lesions can indicate TB complex infection in a prehistoric population. However, it is important to note that lesions that resemble TB can arise from multiple causes, and such causes cannot always be differentiated. This ambiguity, together with the high prevalence of bone lesions at Schild led McGrath (1988) to argue that diseases other than TB were responsible for the Schild lesions. Thus, while we do not recommend a diagnosis of TB infection solely on the basis of the presence of periosteal reaction on ribs, we do recommend incorporating a close examination of ribs as part of a multi-pronged approach, including both morphological and molecular testing into future research on TB complex prevalence in ancient populations.

\section{REFERENCES}

Braun M, Cook DC, Pfeiffer S 1998. DNA from Mycobacterium tuberculosis complex identified in North American, pre-Columbian human skeletal remains. J Archeol Sci 25: 271-277.

Buikstra JE 1977. Differential diagnosis: an epidemiological model. Yrbk Phys Anthropol 20: 316-328.

Buikstra JE, Cook DC 1981. Pre-Columbian tuberculosis in West-Central Illinois: prehistoric disease in biocultural perspective. In JE Buikstra, Prehistoric Tuberculosis in the
Americas, Northwestern University Archaeological Program, Evanston, p. 115-139.

Buikstra JE, Williams S 1991. Tuberculosis in the Americas: current perspectives. In DJ Ortner, AC Aufderheide (eds), Human Paleopathology: Current Syntheses and Future Options, Smithsonian Institution Press, Washington, p. 161172.

Cook DC 1980. Appendix C. Schild Pathologies. In LG Goldstein, Mississippian Mortuary Practices: a Case Study of Two Cemeteries in the Lower Illinois Valley, Northwestern University Archeological Program Scientific Papers No. 4, Evanston, p. 160-163.

Daniel TM, Oxtoby MJ, Pinto E, Moreno E 1981. The immune system in patients with pulmonary tuberculosis. Am Rev Respir Dis 123: 556-559.

Eyler WH, Monsein LH, Beute GH, Tilley B, Schultz LR, Schmitt WGH 1996. Rib enlargement in patients with chronic pleural disease. Am J Radiol 167: 921-926.

Kelly MA, Micozzi MS 1984. Rib lesions and chronic pulmonary tuberculosis. Am J Phys Anthropol 65: 381-386.

Lambert PM 2002. Rib lesions in a prehistoric Puebloan sample from southwestern Colorado. Am J Phys Anthropol 117: 281-292.

Matos V, Santos AL 2006. On the trail of pulmonary tuberculosis based on rib lesions: results from the Human Identified Skeletal Collection from the Museu Bocage (Lisbon, Portugal). Am J Phys Anthropol 130: 190-200.

Mays S, Fysh E, Taylor GM 2002. Investigation of the link between visceral surface rib lesions and tuberculosis in a medieval skeletal series from England using ancient DNA. Am J Phys Anthropol 119: 27-36.

McGrath JW 1988. Social networks of disease spread in the lower Illinois valley: a simulation approach. Am J Phys Anthropol 77: 483-496.

Merbs CF 1992. A New World of infectious disease. Ybk Phys Anthropol 35: 3-42.

Milner G 1998. The Cahokia Chiefdom: the Archaeology of a Mississippian Society, Smithsonian Institution Press, Washington, $216 \mathrm{pp}$.

Pfeiffer S 1991. Rib lesions and New World tuberculosis. Int $J$ Osteoarchaeol 1: 191-198.

Roberts CA, Buikstra JE 2003. The Bioarchaeology of Tuberculosis: a Global View on a Reemerging Disease, University Press of Florida, Gainesville, 343 pp.

Roberts C, Lucy D, Manchester K 1994. Inflammatory lesions of ribs: an analysis of the Terry Collection. Am J Phys Anthropol 95: 169-182.

Santos AL, Roberts CA 2001. Anatomy of a serial killer: differential diagnosis based on rib lesions from the Coimbra Identified Skeletal Collection. Am J Phys Anthropol 32 (Suppl.): 130 [abstract].

Smith I 2003. Mycobacterium tuberculosis pathogenesis and molecular determinants of virulence. Clin Microbiol Rev 16: 463-496. 
